\title{
Measuring Height Characteristics of Sagebrush (Artemisia sp.) Using Imagery Derived from Small Unmanned Aerial Systems (sUAS)
}

\author{
Ryan G. Howell ${ }^{1, * \mathbb{D}}$, Ryan R. Jensen ${ }^{2}$, Steven L. Petersen ${ }^{1}$ and Randy T. Larsen ${ }^{1}$ \\ 1 Department of Plant and Wildlife Sciences, 4105B LSB, Brigham Young University, Provo, UT 84602, USA; \\ steven_petersen@byu.edu (S.L.P.); randy_larsen@byu.edu (R.T.L.) \\ 2 Department of Geography, Brigham Young University, Provo, UT 84602, USA; ryan.jensen@byu.edu \\ * Correspondence: howell.ryan12@gmail.com
}

Received: 24 December 2019; Accepted: 14 February 2020; Published: 19 February 2020

check for updates

\begin{abstract}
In situ measurements of sagebrush have traditionally been expensive and time consuming. Currently, improvements in small Unmanned Aerial Systems (sUAS) technology can be used to quantify sagebrush morphology and community structure with high resolution imagery on western rangelands, especially in sensitive habitat of the Greater sage-grouse (Centrocercus urophasianus). The emergence of photogrammetry algorithms to generate 3D point clouds from true color imagery can potentially increase the efficiency and accuracy of measuring shrub height in sage-grouse habitat. Our objective was to determine optimal parameters for measuring sagebrush height including flight altitude, single- vs. double- pass, and continuous vs. pause features. We acquired imagery using a DJI Mavic Pro 2 multi-rotor Unmanned Aerial Vehicle (UAV) equipped with an RGB camera, flown at 30.5, 45, 75, and $120 \mathrm{~m}$ and implementing single-pass and double-pass methods, using continuous flight and paused flight for each photo method. We generated a Digital Surface Model (DSM) from which we derived plant height, and then performed an accuracy assessment using on the ground measurements taken at the time of flight. We found high correlation between field measured heights and estimated heights, with a mean difference of approximately $10 \mathrm{~cm}(\mathrm{SE}=0.4 \mathrm{~cm})$ and little variability in accuracy between flights with different heights and other parameters after statistical correction using linear regression. We conclude that higher altitude flights using a single-pass method are optimal to measure sagebrush height due to lower requirements in data storage and processing time.
\end{abstract}

Keywords: greater sage-grouse; sagebrush; sUAS; photogrammetry

\section{Introduction}

Small Unmanned Aerial Systems (sUAS) are advancing at a rapid rate, thereby greatly expanding our ability to acquire high-resolution imagery for lower costs than relying on imagery acquired by satellite or manned-aircraft only. Additionally, the degree of automation involved in modern sUAS allows a less experienced pilot to acquire high-resolution imagery [1]. Many sUAS are able to be fitted with cameras capable of acquiring imagery at finer spatial and spectral resolution [2] than other satellite or fixed-winged aircraft systems. sUAS may collect data using thermal, near infrared (NIR), and Light Detection and Ranging (LiDAR) sensors to aid in image classification. Although not a perfect solution, use of sUAS usually decreases cost, time, and subjectivity of data collection compared to in situ measurements [3].

Photogrammetry is a technology that analyzes overlap between RGB photos by examining features common in multiple images from different look angles and generates a three-dimensional point cloud which can be used to create Digital Terrain Models (DTMs), Digital Surface Models (DSMs), and 
calculate plant height and structure by subtracting the DTM from the DSM (also known as DEM of Difference) [3-8]. Results are similar to data acquired by LiDAR [9-13], but come with advantages and disadvantages: data can be acquired with a standard RGB camera instead of a usually more expensive sensor $[10,14]$, while the inability of the RGB camera to penetrate dense canopies can inhibit the construction of an accurate DTM [1,12], thus potentially introducing error into the dataset. Improvements in photogrammetric algorithms have subsequently improved the accuracy of DSMs created from aerial imagery in biometric applications, including forestry and range management, and improvements in computer processing power has made it possible to construct 3D models of progressively larger datasets [12]. However, differences in methods of data collection and their associated accuracies, including flight altitude above ground level (AGL), flight speed (continuous vs. pause and capture), camera angle (nadir vs. 70\% camera angle), and flight pattern (single pass vs. double pass), are understudied in rangeland applications [5].

The sagebrush-steppe ecosystem in the western United States is a primarily sagebrush (Artemisia spp.) dominant landscape of great ecological concern $[15,16]$. Sagebrush cover has decreased by approximately $40 \%-50 \%[17,18]$ throughout much of its range, due mainly to anthropogenic factors (e.g., overgrazing, energy and urban development, recreation). Changes in plant community structure due to increased invasive plants and changes in fire regimes have also contributed greatly to the alteration of sagebrush dominated landscapes [19-21].

Reduced sagebrush habitats have been detrimental to several obligate and facultative wildlife species. For instance, greater sage-grouse (Centrocercus urophasianus), hereafter sage-grouse, are a sagebrush obligate species that has seen dramatic declines in population density throughout their range [22]. Sage-grouse dependence on sagebrush extends throughout all seasons and life stages, with sagebrush height being a vital attribute of brood-rearing and nesting habitat and winter range [23-26]. As a result of their moderate reproductive rates [27,28], and the direct correlation between nest/brood success and sagebrush structure [19], it is vital for land managers to understand changes in sagebrush habitat in areas they manage.

Land managers have focused for decades on quantifying sagebrush habitat using traditional on the ground measurement techniques to determine plant height, percent cover, frequency, and density [29-31]. While these measurements are typically effective, they can also be time consuming, expensive, and subject to the skill of the data collector [3,10,32]. However, measurements using remote sensing have in large part been found to complement many ground measurements across landscapes [12,19,32,33].

\section{Study Objectives and Hypotheses}

Our objectives were to (1) determine if photogrammetry is a viable method of measuring sagebrush height and (2) determine the most time efficient method to acquire sagebrush imagery (taking into account time and accuracy). We hypothesized that lower flight height, double pass flight patterns, and the drone pause method will yield higher accuracy but greatly increase flight time. We thus predicted that the optimal combination of parameters for moderate flight time with acceptable accuracy will be achieved at $75 \mathrm{~m}$ AGL using a single pass and continuous flight method.

\section{Methods and Materials}

\subsection{Study Area}

We acquired imagery on a 5.75 ha plot near Trout Creek, Utah, located east of the Wasatch Mountains and south of the Uinta Mountains in east-central Utah $\left(40.232107^{\circ} \mathrm{N}, 111.118933^{\circ} \mathrm{W}\right.$, Figure 1). The dominant feature near the study area is the Strawberry Reservoir, which covers approximately 2500 ha. The terrain within the study area is relatively flat with a mean elevation of approximately $2350 \mathrm{~m}$. Mean annual precipitation is $79 \mathrm{~cm}$ [34], with cool summers $\left(13.5^{\circ} \mathrm{C}\right.$ mean air temperature) and cold winters $\left(-8.7^{\circ} \mathrm{C}\right.$ mean air temperature). Mountain big sagebrush (Artemisia 
tridentata spp. vaseyana) is a tall, amorphous, typically flat-topped shrub that generally does not exceed $180 \mathrm{~cm}$ in height, but may exceed $240 \mathrm{~cm}$ in height [35,36], and is the dominant shrub with a rich diversity of intercanopy grasses and forbs (Figure 2).

The population of sage-grouse in Strawberry Valley, Utah has plummeted from 3-4000 in the late 1930s [37] to less than 200 in the late 1990s [38] due to habitat fragmentation and degradation caused by anthropogenic expansion [39], the introduction of the invasive red fox (Vulpes vulpes) [40], and genetic bottleneck [41,42]. Sagebrush was treated within the study area in 2006-2007 and retreated in 2017 using a Dixie Harrow, implemented to decrease total sagebrush cover and improve brood-rearing habitat conditions for sage-grouse $[23,43]$. We included both treated and untreated areas in our study area.

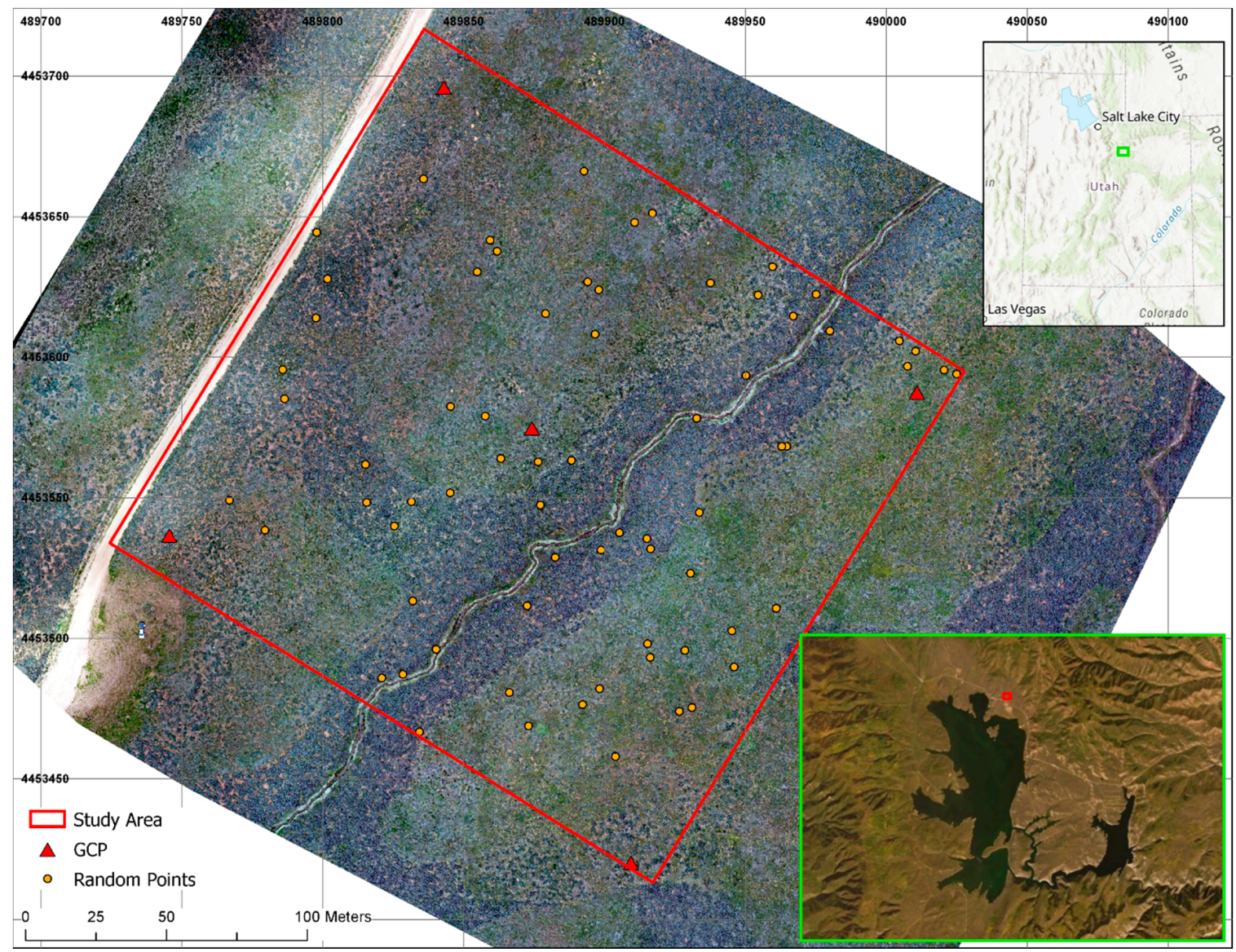

Figure 1. Study area near Trout Creek, just north of US 40 near Strawberry Reservoir, Utah, USA.

\subsection{Data Collection}

We acquired sUAS RGB imagery using a consumer-grade DJI Mavic Pro 2 quadcopter with an RGB camera (Table 1) piloted by a Federal Aviation Administration (FAA) Part 107 certified remote pilot from 7 June-21 June 2019. All flights occurred within $2 \mathrm{~h}$ of solar noon (13:23 to 13:26) to minimize shadows [3]. Images were acquired with $85 \%$ front overlap and $70 \%$ side overlap, meeting the recommended minimum provided by Pix4D (Pix4D, Lausanne, Switzerland) as well as previous research [5]. The flights were automated for waypoint control and image capture using the Pix4D Capture mobile app using each combination of the following parameters:

1. Height: $30.5 \mathrm{~m}$ AGL, $45 \mathrm{~m}$ AGL, $75 \mathrm{~m}$ AGL, and $120 \mathrm{~m}$ AGL

Pre-flight calculations of spatial resolutions range from approximately $0.75 \mathrm{~cm}(30.5 \mathrm{~m})$ to approximately $3 \mathrm{~cm}$ (120 m, Table 2). Higher resolution (lower Ground Sampling Distance, GSD) 
is expected to result in higher accuracy of photogrammetrically derived plant height values [44]. In addition, higher flights have a higher viewing angle, which we predict will negatively impact our ability to achieve an oblique view for optimal point cloud generation. Flight time decreases by roughly half with each successive increase in height AGL (Table 2).

2. Flight pattern: Single pass vs. Double pass with non-nadir imagery

Single pass methods decrease flight time compared to double pass (or quadruple pass, which we did not test in this study). Double pass methods are expected to improve point cloud generation by utilizing the multiple viewing angles of each plant with non-nadir imagery (camera angle of about $70 \%$ ). Flight time is roughly doubled by implementing a double pass flight (Table 2).

3. Flight Speed: Continuous mode vs. Safe mode

Lower heights are more susceptible to motion blur using continuous flight methods ("Continuous mode"), while pausing the drone, taking a picture, and resuming flight ("Safe mode") decreases the risk of blur and improves overall image quality, which is also expected to aid in point cloud generation. Flight time is roughly tripled by implementing safe mode (Table 2).

Table 1. DJI Mavic Pro 2 specs for both camera and aircraft, as specified by DJI (https://www.dji.com/ mavic-2/info).

\begin{tabular}{cc}
\hline Camera & \\
\hline CMOS & $1^{\prime \prime}$ \\
Megapixels & 20 \\
Lens & $\mathrm{F} / 2.8-11$ \\
FOV & $77^{\circ}$ \\
Electrical Rolling Shutter & $8-1 / 8000 \mathrm{~s}$ \\
Resolution & $5472 \times 3648$ \\
ISO range & $100-12,800$ \\
\hline Aircraft & \\
Takeoff weight & $907 \mathrm{~g}$ \\
Max flight time & $31 \mathrm{~min}$ \\
Max Speed & $72 \mathrm{kph}$ \\
\hline
\end{tabular}

Table 2. Summary of pre-flight estimated flight time and estimated Ground Sampling Distance (GSD) for each flight combination (by height, single or double pass, and continuous or safe mode). All values were calculated by the Pix4d Capture mobile app using a DJI Mavic Pro 2 quadcopter.

\begin{tabular}{cccc}
\hline Height AGL (m) & Flight & Time & Resolution (cm) \\
\hline \multirow{3}{*}{30.5} & Single Pass/Continuous & $46 \min 14 \mathrm{~s}$ & 0.71 \\
& Double Pass/Continuous & $91 \min 26 \mathrm{~s}$ & 0.76 \\
& Single Pass/Safe & $122 \min 19 \mathrm{~s}$ & 0.71 \\
\hline \multirow{3}{*}{45} & Single Pass/Continuous & $23 \min 26 \mathrm{~s}$ & 1.06 \\
& Double Pass/Continuous & $46 \min 2 \mathrm{~s}$ & 1.14 \\
& Single Pass/Safe & $62 \min 29 \mathrm{~s}$ & 1.06 \\
\hline \multirow{2}{*}{75} & Single Pass/Continuous & $11 \min 30 \mathrm{~s}$ & 1.77 \\
& Double Pass/Continuous & $21 \min 20 \mathrm{~s}$ & 1.9 \\
& Single Pass/Safe & $30 \min 58 \mathrm{~s}$ & 1.77 \\
\hline \multirow{4}{*}{$\mathbf{1 2 0}$} & Single Pass/Continuous & $6 \min 55 \mathrm{~s}$ & 2.79 \\
& Double Pass/Continuous & $11 \min 45 \mathrm{~s}$ & 2.91 \\
& Single Pass/Safe & $17 \min 30 \mathrm{~s}$ & 2.79 \\
\hline
\end{tabular}


We measured plant height in situ immediately following the flights using a tape measure and a Trimble GeoExplorer 6000 GPS unit at the sagebrush plant nearest 69 randomly distributed points (Figure 1) generated using ArcGIS Pro 2.3 (ESRI, Redlands, CA, USA). Each point was at least $2 \mathrm{~m}$ away from every other point to eliminate double measuring shrubs. Maximum height is the attribute most easily measured by photogrammetry [9]; therefore, we measured the tallest point of each random sagebrush, with and without inflorescence. We also measured each random shrub at the widest point to determine the maximum radius of the plant, which we used to determine the tallest point within a buffer specified by the radius using the Zonal Statistics tool in ArcGIS Pro 2.3 to minimize the effect of error on locating the tallest point of the plant. In addition, we determined the exact altitude of the ground beneath each random sagebrush plant to compare with our DTM. Additionally, we used a total of 5 ground control points (GCPs), marked using the Trimble GPS unit, to georeference our imagery.

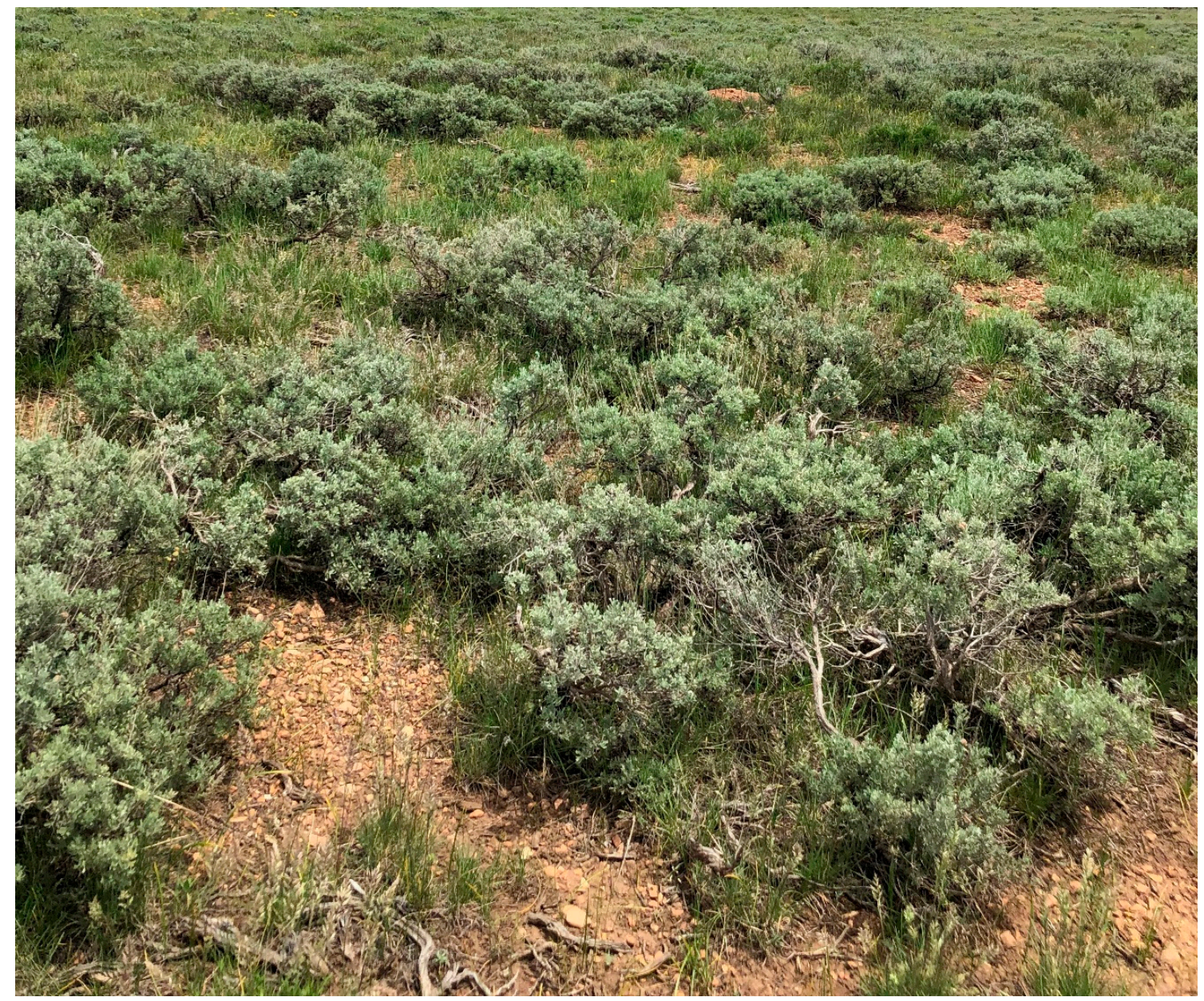

Figure 2. On the ground view of a mountain big sagebrush (Artemisia tridentata spp. vaseyana) system near Trout Creek, Utah.

\subsection{Data Analysis}

We processed the RGB images using Pix4Dmapper for Desktop (Pix4D, Lausanne, Switzerland) to mosaic the images and generate photogrammetric 3D point clouds. This software uses key points to determine common locations between images and computes tie points from which a point cloud and digital surface model (DSM) in a raster format is created. The DSM shows the highest point at each location, while a DTM utilizes a point classification to determine bare ground values by interpolating areas between points classified as "bare ground". These two layers can be used to determine plant height by subtracting the DTM from the DSM (Figure 3). Using this plant height layer, we compared 
computer generated height data with the in situ data. Images were processed using a 64 bit Windows 10 operating system, equipped with an Intel(R) Core(TM) i7-8700 CPU @ 3.20 GHz and 16 GB of RAM. We processed each flight as one project in Pix4D, with the exception of projects with over 1000 images (Table 3). Additionally, we processed the $30 \mathrm{~m}$ double continuous flight using 32GB of RAM due to insufficient RAM on the 16 GB machine and to eliminate the potential error and bias of processing in approximately 8 sub-projects.

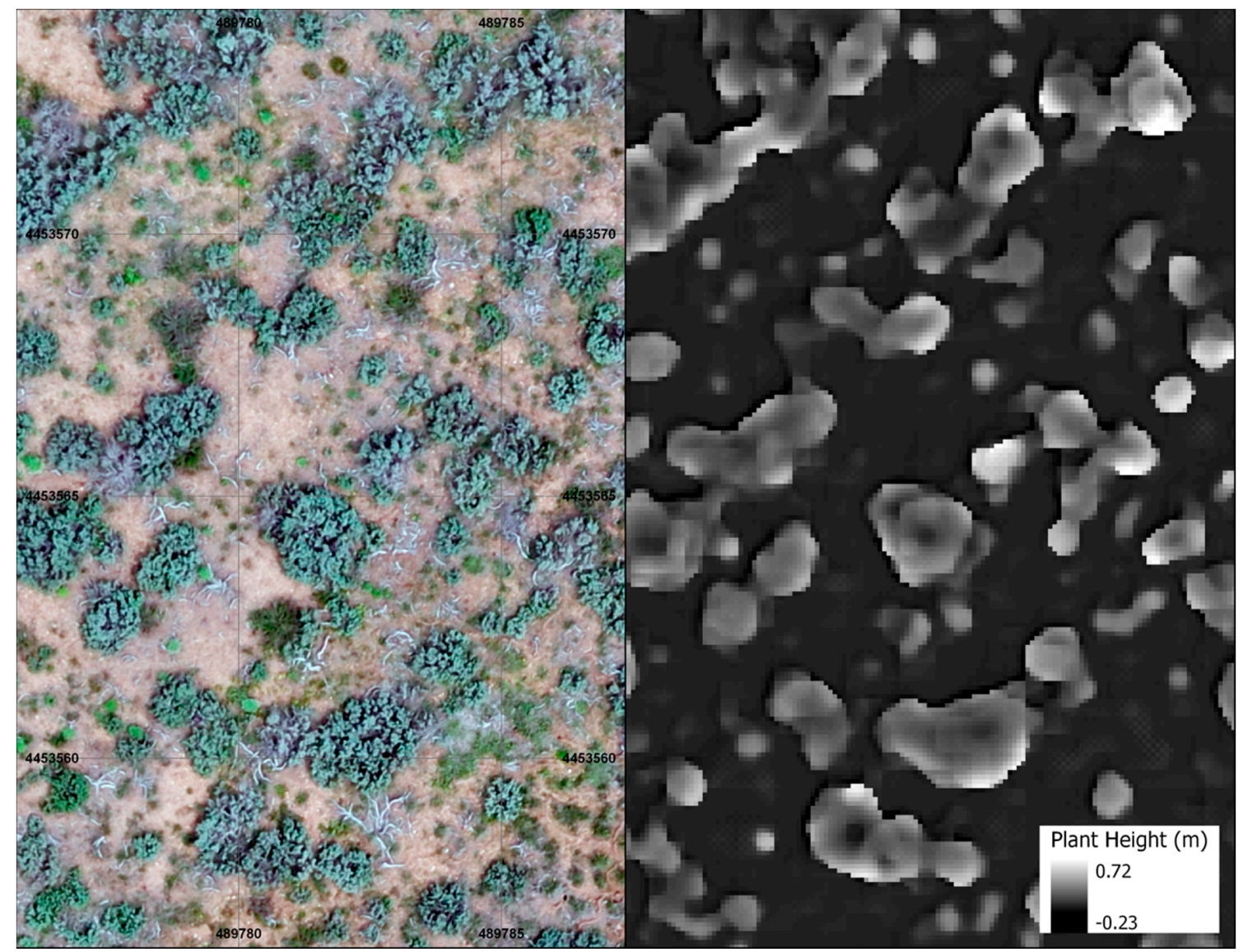

Figure 3. Comparison of RGB imagery (left) with a plant height layer, derived from subtracting the Digital Terrain Model (DTM) from the Digital Surface Model (DSM, right) acquired using a DJI Mavic Pro 2 quadcopter at $75 \mathrm{~m}$ above ground level (AGL) near Strawberry Reservoir, Utah, USA. 
Table 3. Summary of flight results, including number of images, spatial resolution, RMSE, and $R^{2}$ values for plant height and Digital Terrain Model (DTM). Imagery was acquired near Strawberry Reservoir, Utah, USA using a DJI Mavic Pro 2 quadcopter and processed using Pix4D. Images were processed using a 64 bit Windows 10 operating system, equipped with an Intel(R) Core(TM) i7-8700 CPU @ 3.20GHz and 16GB of RAM (with the exception of the $30.5 \mathrm{~m}$ double continuous flight, which was processed using $32 \mathrm{~GB}$ of RAM.

\begin{tabular}{|c|c|c|c|c|c|c|c|c|c|}
\hline $\begin{array}{l}\text { Height AGL } \\
\text { (m) }\end{array}$ & Flight & $\begin{array}{c}\text { \# of } \\
\text { Images }\end{array}$ & $\begin{array}{l}\text { Processing Time } \\
\text { (Minutes) }\end{array}$ & $\begin{array}{c}\text { Average DSM } \\
\text { GSD }(\mathrm{cm})\end{array}$ & $\begin{array}{c}\text { Average DTM/Height } \\
\text { GSD (cm) }\end{array}$ & $\begin{array}{l}\text { RMSE } \\
\text { (Mosaic) }\end{array}$ & $\begin{array}{c}\text { RMSE } \\
\text { (Height) }\end{array}$ & $\begin{array}{c}\text { Plant } \\
\text { Height } R^{2}\end{array}$ & DTM $R^{2}$ \\
\hline \multirow{7}{*}{30.5} & & & & & & Sub 1: $<0.001$ & Sub 1: 0.05 & & \\
\hline & Single Continuous ${ }^{b}$ & 1244 & 2453 & 0.62 & 3 & Sub 2: 0.0678 & Sub 2: $<0.001$ & 0.5851 & 0.9695 \\
\hline & & & & & & Sub 3: $<0.001$ & Sub 3: $<0.001$ & & \\
\hline & Double Continuous $^{\mathrm{c}}$ & 2402 & 3210 & 0.69 & 3.4 & 0.5656 & 0.0127 & 0.4319 & 0.9195 \\
\hline & & & & & & Sub 1: $<0.001$ & Sub 1: $<0.001$ & & \\
\hline & Single Safe ${ }^{b}$ & 1251 & 2099 & 0.6 & 3 & Sub 2: $<0.001$ & Sub 2: 0.005 & 0.4711 & 0.8811 \\
\hline & & & & & & Sub 3: $<0.001$ & Sub 3: $<0.001$ & & \\
\hline \multirow{4}{*}{45} & Single Continuous & 567 & 1232 & 0.98 & 4.9 & 0.142 & 0.015 & 0.5204 & 0.9281 \\
\hline & Double Continuous a & 1188 & 1425 & 1.11 & 5.5 & Sub 1: $<0.001$ & Sub 1: $<0.001$ & 0.4244 & 0.9591 \\
\hline & & & & & 0.0 & Sub 2: $<0.001$ & Sub 2: 0.03636 & 0.4244 & \\
\hline & Single Safe & 567 & 1212 & 1 & 4.9 & 0.0604 & 0.0095 & 0.5774 & 0.9769 \\
\hline \multirow{3}{*}{75} & Single Continuous & 240 & 570 & 1.74 & 8.7 & 0.1442 & 0.011 & 0.482 & 0.964 \\
\hline & Double Continuous & 481 & 920 & 1.97 & 9.8 & 0.0655 & 0.0506 & 0.5631 & 0.9948 \\
\hline & Single Safe & 239 & 473 & 1.72 & 8.5 & 0.0713 & 0.0957 & 0.5515 & 0.9914 \\
\hline \multirow{3}{*}{120} & Single Continuous & 111 & 262 & 2.74 & 13.7 & 0.076 & 0.112 & 0.5297 & 0.9842 \\
\hline & Double Continuous & 219 & 681 & 3.13 & 15.6 & 0.0417 & 0.037 & 0.5815 & 0.9777 \\
\hline & Single Safe & 111 & 314 & 2.86 & 14.3 & 0.074 & 0.105 & 0.6162 & 0.9849 \\
\hline
\end{tabular}

${ }^{a}$ processed in 2 sub-projects; ${ }^{b}$ processed in 3 sub-projects; ${ }^{c}$ processed using 32 GB of RAM. 
Based on previous experience, we determined the optimal settings for generating a point cloud and subsequent DTM and DSM layers. Within the Pix4D processing settings, we set the image scale (the scale at which 3D points are computed) to full image size and the minimum number of matches to 3 (meaning each 3D point must be projected in at least 3 images). Default settings were left for the point density of the densified point cloud (optimal, or 4/Image Scale), resolution of the DSM $(1 \times \mathrm{GSD})$, and DTM resolution $(5 \times$ GSD). Images were processed in Pix 4 D using UTM $12 \mathrm{~N}$ as the coordinate system and the WGS84 datum.

After processing the imagery, we compared the height values calculated by Pix $4 \mathrm{D}$ (found in the plant height layer derived from subtracting the DTM from the DSM) with the in situ values measured in the field using a regression analysis for each flight. Comparing computed values with on the ground values provided $R^{2}$ values to determine correlation as well as the equation for the regression line, which we applied to the values derived from the height layer at each of the points used for the accuracy assessment. This method provided a statistical correction to aid in calibrating the height values across the entire dataset.

We reported all mean values as mean \pm s.e.

\section{Results}

We performed flights according to the parameters set forth above. Temperatures during data collection ranged from $7.75^{\circ} \mathrm{C}$ to $19^{\circ} \mathrm{C}$, with winds ranging from calm to approximately $19 \mathrm{kph}$. Cloud cover was mostly sunny, with occasional cover occurring during some of the flights, although we made every effort to fly in perfectly sunny conditions with no wind. The number of images per flight ranged from 111 images for the Single Pass flights at $120 \mathrm{~m}$ to 2402 images for the Double Pass flight at $30.5 \mathrm{~m}$ (Table 3). Additionally, GSD of the DSM ranged from $0.6 \mathrm{~cm}$ to $3.13 \mathrm{~cm}$ (Table 3). Each flight had high correlation between the two elevation values (ground truth measured at the base of each sagebrush plant and those derived from the DTM), with $R^{2}$ values of at least 0.9 for each flight (with the exception of one flight, Table 3).

We measured a total of 69 sagebrush plants within the study site to the highest point. Individual shrubs ranged from $14 \mathrm{~cm}-84 \mathrm{~cm}$, with the mean shrub being $37 \mathrm{~cm} \pm 1.8 \mathrm{~cm}$. The measured points for each flight had a tendency to underestimate shrub height compared to true height on the ground, with mean differences ranging from 11 to approximately $30 \mathrm{~cm}$ (mean $21 \mathrm{~cm} \pm 1.8 \mathrm{~cm}$, Figure 4). However, correlation between measured and true heights was high for most flights, ranging from approximately 0.4 to 0.6 (Table 3, Figure 5). In the case of the $30 \mathrm{~m}$ and $45 \mathrm{~m}$ double continuous flights, random points were removed from analysis ( 9 points and 4 points, respectively) due to processing errors that resulted in unrealistic plant height values.

We used linear regression to correct differences between measured and true heights. By applying the regression line to the measured value at each of our random points, the mean difference between measured shrub height and true shrub height decreased to $8 \mathrm{~cm}-13.5 \mathrm{~cm}$ (mean $10.7 \mathrm{~cm} \pm 0.4 \mathrm{~cm}$, Table 4). Additionally, approximately $80 \%$ of points are within $20 \mathrm{~cm}$ and over $50 \%$ are within $10 \mathrm{~cm}$ of true values, depending on the flight (Table 5). 


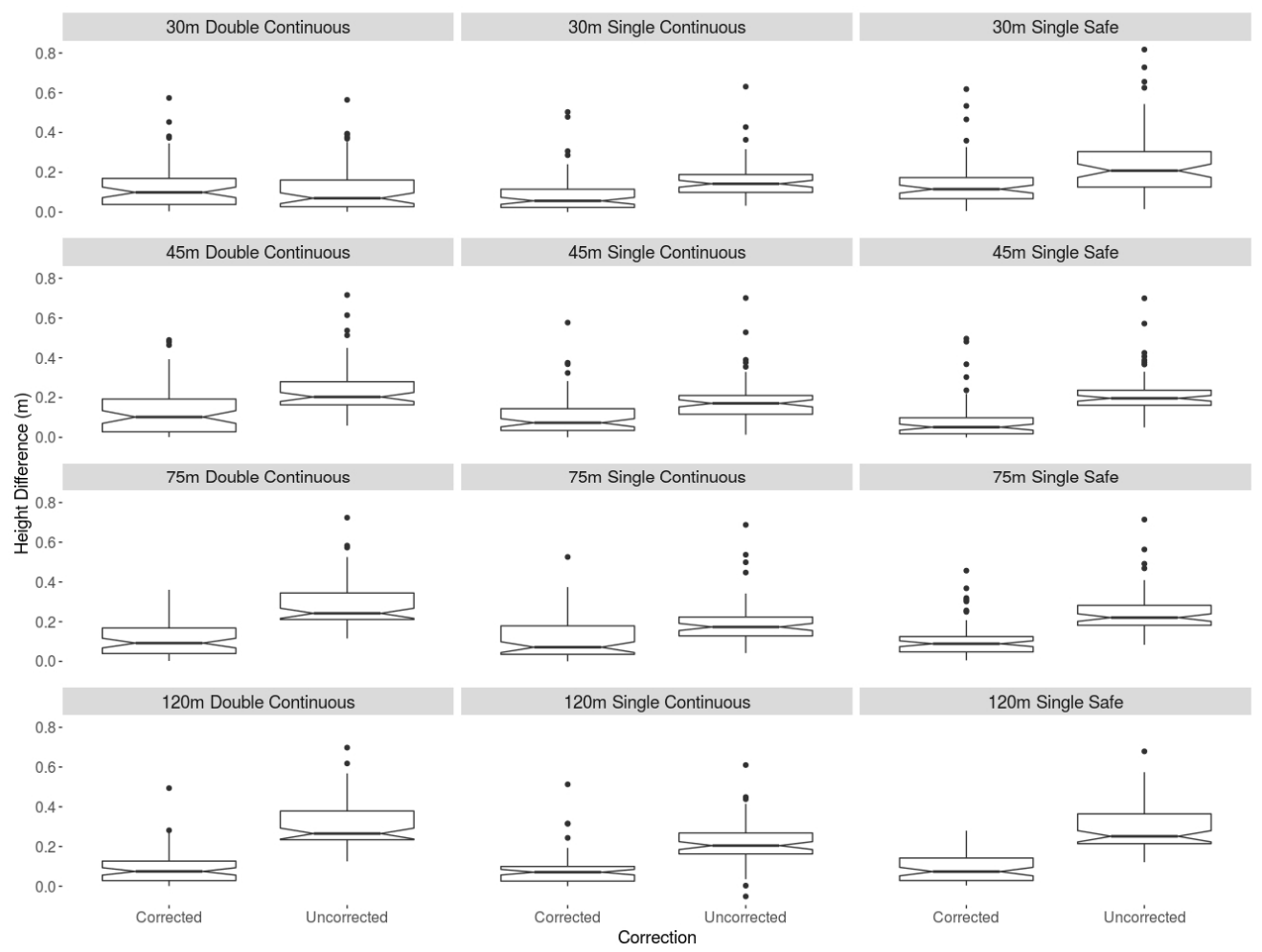

Figure 4. Absolute value of differences between true height and measured height $(\mathrm{m})$, for both uncorrected (right plot) and corrected using linear regression (left plot) for each flight parameter combination (by height, single or double pass, and continuous or safe mode).
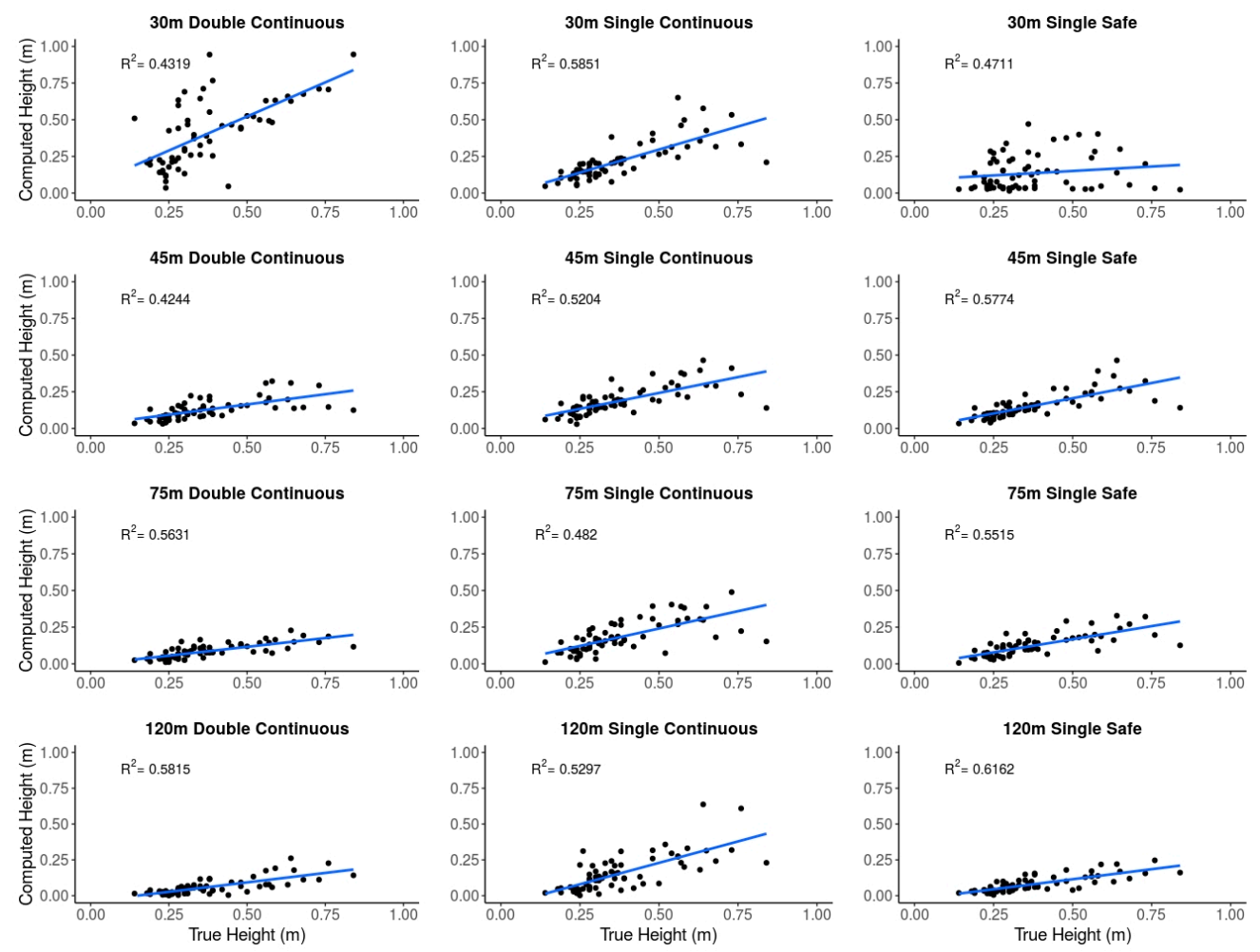

Figure 5. Regression plots for each flight parameter combination (by height, single or double pass, and continuous or safe mode) comparing true height in meters (x-axis) and computed height in meters (y-axis). 
Table 4. Summary of corrected and uncorrected average difference between measured and derived shrub heights. Imagery was acquired near Strawberry Reservoir, Utah, USA using a DJI Mavic Pro 2 quadcopter and processed using Pix4D.

\begin{tabular}{|c|c|c|c|c|c|}
\hline $\begin{array}{l}\text { Height AGL } \\
(\mathrm{m})\end{array}$ & Flight & $\begin{array}{c}\text { Uncorrected Average Difference } \\
\text { Shrub Height }(\mathrm{m})\end{array}$ & Uncorrected SE & $\begin{array}{c}\text { Corrected Average Difference } \\
\text { Shrub Height (m) }\end{array}$ & Corrected SE \\
\hline \multirow{3}{*}{30.5} & Single Continuous $b$ & 0.1559 & 0.012 & 0.0856 & 0.0118 \\
\hline & Double Continuous ${ }^{\mathrm{c}}$ & 0.1154 & 0.0216 & 0.1311 & 0.0159 \\
\hline & Single Safe ${ }^{b}$ & 0.1372 & 0.0147 & 0.1208 & 0.0132 \\
\hline \multirow{3}{*}{45} & Single Continuous & 0.183 & 0.013 & 0.106 & 0.0123 \\
\hline & Double Continuous $^{a}$ & 0.2427 & 0.0153 & 0.135 & 0.0152 \\
\hline & Single Safe & 0.2195 & 0.0127 & 0.0849 & 0.0121 \\
\hline \multirow{3}{*}{75} & Single Continuous & 0.1923 & 0.0133 & 0.1191 & 0.0128 \\
\hline & Double Continuous & 0.283 & 0.0146 & 0.105 & 0.0101 \\
\hline & Single Safe & 0.2501 & 0.0133 & 0.1063 & 0.108 \\
\hline \multirow{3}{*}{120} & Single Continuous & 0.219 & 0.0128 & 0.1034 & 0.0123 \\
\hline & Double Continuous & 0.3133 & 0.0142 & 0.096 & 0.0107 \\
\hline & Single Safe & 0.2929 & 0.014 & 0.0935 & 0.0094 \\
\hline
\end{tabular}

${ }^{\mathrm{a}}$ processed in 2 sub-projects; ${ }^{\mathrm{b}}$ processed in 3 sub-projects; ${ }^{\mathrm{c}}$ processed using $32 \mathrm{~GB}$ of RAM. 
Table 5. Summary of number and percentage of accuracy assessment points within a given distance of true height for each flight parameter combination (by height, single or double pass, and continuous or safe mode) after applying a regression correction. Imagery was acquired near Strawberry Reservoir, Utah, USA using a DJI Mavic Pro 2 quadcopter and processed using Pix4D.

\begin{tabular}{|c|c|c|c|c|c|c|c|c|c|}
\hline & & \multicolumn{4}{|c|}{ Points Within a: } & \multicolumn{4}{|c|}{ Percent Within: } \\
\hline & & $20 \mathrm{~cm}$ & $15 \mathrm{~cm}$ & $10 \mathrm{~cm}$ & $5 \mathrm{~cm}$ & $20 \mathrm{~cm}$ & $15 \mathrm{~cm}$ & $10 \mathrm{~cm}$ & $5 \mathrm{~cm}$ \\
\hline \multirow{3}{*}{120} & Single Continuous & 60 & 58 & 52 & 29 & 86.96 & 84.06 & 75.36 & 42.03 \\
\hline & Single Safe & 60 & 54 & 46 & 27 & 86.96 & 78.26 & 66.67 & 39.13 \\
\hline & Double Continuous & 59 & 54 & 41 & 27 & 85.51 & 78.26 & 59.42 & 39.13 \\
\hline \multirow{3}{*}{75} & Single Continuous & 55 & 47 & 37 & 23 & 79.71 & 68.12 & 53.62 & 33.33 \\
\hline & Single Safe & 61 & 57 & 41 & 20 & 88.41 & 82.61 & 59.42 & 28.99 \\
\hline & Double Continuous & 64 & 50 & 38 & 24 & 92.75 & 72.46 & 55.07 & 34.78 \\
\hline \multirow{3}{*}{45} & Single Continuous & 59 & 53 & 44 & 25 & 85.51 & 76.81 & 63.77 & 36.23 \\
\hline & Single Safe & 62 & 59 & 52 & 37 & 89.86 & 85.51 & 75.36 & 53.62 \\
\hline & Double Continuous ${ }^{b}$ & 52 & 43 & 33 & 22 & 80.00 & 66.15 & 50.77 & 33.85 \\
\hline \multirow{3}{*}{30.5} & Single Continuous & 64 & 60 & 50 & 33 & 92.75 & 86.96 & 72.46 & 47.83 \\
\hline & Single Safe & 57 & 52 & 41 & 22 & 82.61 & 75.36 & 59.42 & 31.88 \\
\hline & Double Continuous ${ }^{\mathrm{c}}$ & 49 & 44 & 33 & 19 & 81.67 & 73.33 & 55.00 & 31.67 \\
\hline
\end{tabular}

${ }^{a}$ out of $69 ;{ }^{b}$ out of 65 (points removed due to processing errors); ${ }^{c}$ out of 60 (points removed due to processing errors). 


\section{Discussion}

Photogrammetry was an accurate method to measure elevation by creating a DTM in our study area. Due to the high correlation we observed between true elevation and elevation obtained using photogrammetry, as well as the unvarying terrain and relatively sparse vegetation within our site, we do not expect that DTM generation negatively affected our results. However, although much of the sage-steppe ecosystem exhibits similar landscape characteristics, care should be exercised in areas of more extreme topographic variation or dense vegetation.

Additionally, using photogrammetry was a reasonable method to predict sagebrush height before statistical correction, with accuracies for the $120 \mathrm{~m}$ flights similar to or better than what has been reported using LiDAR, but with a slightly lower correlation (with LiDAR being accurate within approximately $28 \mathrm{~cm}$, with an $R^{2}$ of 0.84) [45]. Each step decrease in flight height AGL improved accuracy with similar $R^{2}$ as the $120 \mathrm{~m}$ flights (Tables 3 and 4 ). We also observed a general underestimation of shrub height using this method, as has been reported elsewhere [3,45-47], presumably due to differences in field measurement methods (e.g., maximum height) versus how computed heights are derived from imagery; for example, the highest point might be too fine to be detected in the imagery. Using control points to perform a statistical correction using linear regression shows promise in further calibrating an image across an entire landscape. This is particularly useful in the sagebrush-steppe ecosystem (and similar systems in other parts of the world) as taking few ground measurements can help to construct a height model over large areas, decreasing time required for field measurements. Overall, we found that measurements derived using photogrammetry are similar to those expected from LiDAR, and the relatively low cost associated with photogrammetry makes it an attractive alternative [9,11].

Optimal flight parameters to measure sagebrush height, as is the case in many instances in remote sensing, depends on the resources available and question being asked. If a very rough shrub height measurement is all that is required, then the user should select the altitude AGL that correlates with the imagery resolution that is required for the question at hand; or, if no imagery is necessary, the researcher can simply fly at the highest altitude possible to decrease data acquisition and processing time, knowing that the mean error within the dataset will be within approximately $30 \mathrm{~cm}$ (Table 4). Similarly, we found negligible differences in accuracy between flights if statistical correction using linear regression is applied, with all flights having a mean difference of around $10 \mathrm{~cm}$ (Table 4). In this case, the user could opt to fly at the highest altitude possible to decrease data acquisition and processing time. If statistical correction is not an option and the user has higher amounts of processing time and computing power, flights at $30 \mathrm{~m}$ AGL had the lowest uncorrected differences in shrub height (Table 4).

It should be noted that processing time and system requirements are major factors to consider when determining ideal parameters, especially flight altitude AGL. We found that 16 GB of RAM was not enough to process a dataset with over 1000 images without dividing it into subprojects, which requires duplication of efforts to process each dataset and leads to increased potential of human error and bias. Additionally, our machine struggled to process the $30 \mathrm{~m}$, double continuous dataset with over 2000 images due to the smaller amounts of RAM (16 GB). This was resolved by processing with a machine with 32 GB of RAM, which took $53.5 \mathrm{~h}$ to complete. The current growth rate in processing power indicates that this capability will become more and more accessible, but is currently considered a more high-powered machine that may or may not be a limiting factor. This discrepancy will only become more pronounced as datasets are produced to cover a larger area than the relatively small test area in this paper.

The use of sUAS to acquire RGB imagery for photogrammetric height extraction of sagebrush heights is relatively understudied in the literature, but it is comparable to LiDAR in accuracy without the cost of an expensive sensor. With the continuous evolution of sUAS comes reduced costs and greater ease of use, decreasing the amount of specialty training needed to acquire high-resolution imagery. Further research is necessary to continue to determine optimal methods to accurately model sagebrush height and structure and identify other parameters that could affect accuracy (such as 
weather conditions or different levels of overlap), especially over broad scales, but using sUAS derived photogrammetry to measure rangeland attributes could provide a cost effective way to measure sensitive sagebrush-steppe ecosystems.

Author Contributions: Conceptualization, R.G.H., S.L.P., R.R.J.; methodology, R.G.H., S.L.P., R.R.J.; software, R.G.H. and R.R.J.; formal analysis, R.G.H.; resources, R.G.H., S.L.P., R.R.J., R.T.L.; data curation, R.G.H.; writing—original draft preparation, R.G.H.; writing—review and editing, R.G.H., R.R.J., S.L.P., R.T.L.; visualization, R.G.H. and R.T.L.; funding acquisition, S.L.P. and R.T.L. All authors have read and agreed to the published version of the manuscript.

Funding: This research was funded by the Utah Reclamation Mitigation and Conservation Commission, grant number R0202518.

Acknowledgments: We thank the Geospatial Habitat Analysis Lab at Brigham Young University for providing equipment for the study, as well as the Wildlife Ecology Lab for providing personnel. We also thank Brigham Young University, the Utah Division of Wildlife Resources, and the Utah Reclamation Mitigation and Conservation Commission for providing funding. Additionally, we thank David Burchfield, Steve Schill, Branden Jeromcheck, Eric Kemp, and Sam Dearing for assistance in study design and field work.

Conflicts of Interest: The authors declare no conflict of interest.

\section{References}

1. Tonkin, T.N.; Midgley, N.G.; Graham, D.J.; Labadz, J.C. The potential of small unmanned aircraft systems and structure-from-motion for topographic surveys: A test of emerging integrated approaches at Cwm Idwal, North Wales. Geomorphology 2014, 226, 35-43. [CrossRef]

2. Rango, A.; Laliberte, A.; Herrick, J.E.; Winters, C.; Havstad, K.; Steele, C.; Browning, D. Unmanned aerial vehicle-based remote sensing for rangeland assessment, monitoring, and management. J. Appl. Remote Sens. 2009, 3, 33542. [CrossRef]

3. Gillan, J.K.; Karl, J.W.; Duniway, M.; Elaksher, A. Modeling vegetation heights from high resolution stereo aerial photography: An application for broad-scale rangeland monitoring. J. Environ. Manag. 2014, 144, 226-235. [CrossRef] [PubMed]

4. Snavely, N.; Seitz, S.M.; Szeliski, R. Modeling the World from Internet Photo Collections. Int. J. Comput. Vis. 2008, 80, 189-210. [CrossRef]

5. Dandois, J.P.; Olano, M.; Ellis, C.E. Optimal Altitude, Overlap, and Weather Conditions for Computer Vision UAV Estimates of Forest Structure. Remote Sens. 2015, 7. [CrossRef]

6. Morino, C.; Conway, S.J.; Balme, M.R.; Hillier, J.; Jordan, C.; Sæmundsson, P.; Argles, T. Debris-flow release processes investigated through the analysis of multi-temporal LiDAR datasets in north-western Iceland. Earth Surf. Process. Landf. 2019, 44, 144-159. [CrossRef]

7. Stylianidis, E.; Akça, D.; Poli, D.; Hofer, M.; Gruen, A.; Sánchez Martín, V.; Smagas, K.; Walli, A.; Altan, O.; Jimeno, E. FORSAT: A 3D forest monitoring system for cover mapping and volumetric 3D change detection. Int. J. Digit. Earth 2019, 1-32. [CrossRef]

8. Díaz-Varela, A.R.; de la Rosa, R.; León, L.; Zarco-Tejada, J.P. High-resolution airborne UAV imagery to assess olive tree crown parameters using 3D photo reconstruction: Application in breeding trials. Remote Sens. 2015, 7, 4213-4232. [CrossRef]

9. Filippelli, S.K.; Lefsky, M.A.; Rocca, M.E. Comparison and integration of lidar and photogrammetric point clouds for mapping pre-fire forest structure. Remote Sens. Environ. 2019, 224, 154-166. [CrossRef]

10. Cunliffe, A.M.; Brazier, R.E.; Anderson, K. Ultra-fine grain landscape-scale quantification of dryland vegetation structure with drone-acquired structure-from-motion photogrammetry. Remote Sens. Environ. 2016, 183, 129-143. [CrossRef]

11. Fonstad, M.A.; Dietrich, J.T.; Courville, B.C.; Jensen, J.L.; Carbonneau, P.E. Topographic structure from motion: A new development in photogrammetric measurement. Earth Surf. Process. Landf. 2013, 38, 421-430. [CrossRef]

12. Wallace, L.; Lucieer, A.; Malenovský, Z.; Turner, D.; Vopěnka, P. Assessment of Forest Structure Using Two UAV Techniques: A Comparison of Airborne Laser Scanning and Structure from Motion (SfM) Point Clouds. Forests 2016, 7, 62. [CrossRef] 
13. Westoby, M.J.; Brasington, J.; Glasser, N.F.; Hambrey, M.J.; Reynolds, J.M. 'Structure-from-Motion' photogrammetry: A low-cost, effective tool for geoscience applications. Geomorphology 2012, 179, 300-314. [CrossRef]

14. Prosek, J.; Simova, P. UAV for mapping shrubland vegetation: Does fusion of spectral and vertical information derived from a single sensor increase the classification accuracy? Int. J. Appl. Earth Obs. Geoinf. 2019, 75, 151-162. [CrossRef]

15. Davies, K.W.; Svejcar, T.J. Comparison of Medusahead-Invaded and Noninvaded Wyoming Big Sagebrush Steppe in Southeastern Oregon. Rangel. Ecol. Manag. 2008, 61, 623-629. [CrossRef]

16. Connelly, J.W.; Knick, S.T.; Schroeder, M.A.; Stiver, S.J. Conservation Assessment of Greater Sage-Grouse and Sagebrush Habitats; Utah State University: Logan, UT, USA, 2004; pp. 1-611.

17. Knick, S.T.; Dobkin, D.S.; Rotenberry, J.T.; Schroeder, M.A.; Vander Haegen, W.M.; Van Riper, C., III. Teetering on the edge or too late? Conservation and research issues for avifauna of sagebrush habitats. Condor 2003, 105, 611-634. [CrossRef]

18. Beck, J.L.; Connelly, J.W.; Wambolt, C.L. Consequences of treating Wyoming big sagebrush to enhance wildlife habitats. Rangel. Ecol. Manag. 2012, 65, 444-455. [CrossRef]

19. Westover, M.; Baxter, J.; Baxter, R.; Day, C.; Jensen, R.; Petersen, S.; Larsen, R. Assessing Greater sage-grouse selection of brood-rearing habitat using remotely-sensed imagery: Can readily available high-resolution imagery be used to identify brood-rearing habitat across a broad landscape? PLOS ONE 2016, 11, e0156290. [CrossRef]

20. Knapp, P.A. Cheatgrass (Bromus tectorum L) dominance in the Great Basin Desert: History, persistence, and influences to human activities. Glob. Environ. Chang. 1996, 6, 37-52. [CrossRef]

21. Walker, B.L.; Naugle, D.E.; Doherty, K.E. Greater sage-grouse population response to energy development and habitat loss. J. Wildl. Manag. 2007, 71, 2644-2654. [CrossRef]

22. Schroeder, M.A.; Aldridge, C.L.; Apa, A.D.; Bohne, J.R.; Braun, C.E.; Bunnell, S.D.; Connelly, J.W.; Deibert, P.A.; Gardner, S.C.; Hilliard, M.A.; et al. Distribution of sage-grouse in North America. Condor 2004, 106, 363-376. [CrossRef]

23. Baxter, J.J.; Baxter, R.J.; Dahlgren, D.K.; Larsen, R.T. Resource selection by greater sage-grouse reveals preference for mechanically-altered habitats. Rangel. Ecol. Manag. 2017, 70, 493-503. [CrossRef]

24. Klebenow, D.A. Sage grouse nesting and brood habitat in Idaho. J. Wildl. Manag. 1969, 33, 649-662. [CrossRef]

25. Drut, M.S.; Crawford, J.A.; Gregg, M.A. Brood habitat use by sage grouse in Oregon. Great Basin Nat. 1994, 54, 170-176.

26. Connelly, J.W.; Schroeder, M.A.; Sands, A.R.; Braun, C.E. Guidelines to manage sage grouse populations and their habitats. Wildlife Soc. Bull. 2000, 28, 967-985.

27. Smith, K.T.; Beck, J.L.; Kirol, C.P. Reproductive state leads to intraspecific habitat partitioning and survival differences in greater sage-grouse: Implications for conservation. Wildl. Res. 2018. [CrossRef]

28. Connelly, J.W.; Hagen, C.A.; Schroeder, M.A. Characteristics and dynamics of greater sage-grouse populations. In Greater Sage-Grouse: Ecology and Conservation of a Landscape Species and Its Habitats; Connelly, S.T.K.a.J.W., Ed.; University of California Press: Berkeley, CA, USA, 2011; Volume 38, pp. 53-67.

29. Canfield, R.H. Application of the Line Interception Method in Sampling Range Vegetation. J. For. 1941, 39, 388-394. [CrossRef]

30. Hanley, T.A. A Comparison of the Line-Interception and Quadrat Estimation Methods of Determining Shrub Canopy Coverage. J. Range Manag. 1978, 31, 60-62. [CrossRef]

31. Boyd, C.S.; Bates, J.D.; Miller, R.F. The Influence of Gap Size on Sagebrush Cover Estimates with the Use of Line Intercept Technique. Rangel. Ecol. Manag. 2007, 60, 199-202. [CrossRef]

32. Seefeldt, S.S.; Booth, D.T. Measuring Plant Cover in Sagebrush Steppe Rangelands: A Comparison of Methods. Environ. Manag. 2006, 37, 703-711. [CrossRef]

33. Hulet, A.; Roundy, B.A.; Petersen, S.L.; Jensen, R.R.; Bunting, S.C. Assessing the Relationship between Ground Measurements and Object-Based Image Analysis of Land Cover Classes in Pinyon and Juniper Woodlands. Photogramm. Eng. Remote Sens. 2013, 79, 799-808. [CrossRef]

34. NRCS. NRCS National Resources Conservation Service. Available online: https://wcc.sc.egov.usda.gov/ nwcc/site? sitenum=435 (accessed on 6 July 2018).

35. Miller, R.F.; Eddleman, L. Spatial and Temporal Changes of Sage Grouse Habitat in the Sagebrush Biome; Utah State University: Logan, UT, USA, 2000. 
36. Tisdale, E. The sagebrush-grass region: A review of the ecological literature [North America]. Idaho. For. 1981, 33, 31 .

37. Griner, L.A. A Study of the Sage Grouse (Centrocercus Urophasianus), with Special Reference to Life History, Habitat Requirements, and Numbers and Distribution; Utah State University: Logan, UT, USA, 1939.

38. Bunnell, K.D. Ecological Factors Limiting Sage Grouse Recovery and Expansion in Strawberry Valley; Utah Brigham Young University: Provo, UT, USA, 2000.

39. Peck, R.D. Seasonal Habitat Selection by Greater Sage Grouse in Strawberry Valley Utah; Brigham Young University: Provo, UT, USA, 2011.

40. Baxter, R.J.; Bunnell, K.D.; Flinders, J.T.; Mitchell, D.L. Impacts of predation on greater sage-grouse in Strawberry Valley, Utah. In Proceedings of the 72nd North American Wildlife and Natural Resources Conference, Portland, OR, USA, 20-24 March 2007.

41. Baxter, R.J.; Flinders, J.T.; Mitchell, D.L. Survival, movements, and reproduction of translocated greater sage-grouse in Strawberry Valley, Utah. J. Wildl. Manag. 2008, 72, 179-186. [CrossRef]

42. Oyler-McCance, S.J.; Taylor, S.E.; Quinn, T.W. A multilocus population genetic survey of the greater sage-grouse across their range. Mol. Ecol. 2005, 14, 1293-1310. [CrossRef] [PubMed]

43. Dahlgren, D.K.; Larsen, R.T.; Danvir, R.; Wilson, G.; Thacker, E.T.; Black, T.A.; Naugle, D.E.; Connelly, J.W.; Messmer, T.A. Greater sage-grouse and range management: Insights from a 25-year case study in Utah and Wyoming. Rangel. Ecol. Manag. 2015, 68, 375-382. [CrossRef]

44. Fraser, R.H.; Olthof, I.; Lantz, T.C.; Schmitt, C. UAV photogrammetry for mapping vegetation in the low-Arctic. Arct. Sci. 2016, 2, 79-102. [CrossRef]

45. Mitchell, J.J.; Glenn, N.F.; Sankey, T.T.; Derryberry, D.R.; Anderson, M.O.; Hruska, R.C. Small-footprint Lidar Estimations of Sagebrush Canopy Characteristics. Photogramm. Eng. Remote Sens. 2011, 77, 521-530. [CrossRef]

46. Streutker, D.R.; Glenn, N.F. LiDAR measurement of sagebrush steppe vegetation heights. Remote Sens. Environ. 2006, 102, 135-145. [CrossRef]

47. Glenn, N.F.; Spaete, L.P.; Sankey, T.T.; Derryberry, D.R.; Hardegree, S.P.; Mitchell, J.J. Errors in LiDAR-derived shrub height and crown area on sloped terrain. J. Arid Environ. 2011, 75, 377-382. [CrossRef]

(C) 2020 by the authors. Licensee MDPI, Basel, Switzerland. This article is an open access article distributed under the terms and conditions of the Creative Commons Attribution (CC BY) license (http://creativecommons.org/licenses/by/4.0/). 